ELIF GULER

Longwood University, United States

\title{
RHETORIC FOR “DIVINE BLISS": THE CULTURAL AND PEDAGOGICAL IMPLICATIONS OF KUT AND TÖRE AS THE PILLARS OF THE TURKISH RHETORICAL TRADITION
}

\begin{abstract}
:
Many reputable universities across the world aim to educate their students as critically thinking and civic-minded individuals who have a commitment to advance their communities. Taking this objective a step further necessitates helping students develop as global citizens who are equipped with rhetorical tools from different cultures and nations-as rhetoric (the ancient art of speaking and writing) is at the heart of civic and professional actions. To this end, my research aims to recover non-Western approaches to rhetoric, by focusing on the rhetorical perspectives and practices of my native Turks-a group whose world presence spans centuries since their ancient origins in central Asia, and to explore their rhetorical and pedagogical implications for contemporary students and citizens.
\end{abstract}

This presentation will focus on a thematic analysis of the first major example of Turkish-Islamic literature (11th century), Yusuf Has Hacib's Kutadgu Bilig (roughly translated as Wisdom That Brings Happiness), which deems the appropriate use of language essential to living a fulfilled life. I will discuss Kutadgu Bilig's teachings on how to use language, explaining the text's aim to educate an 'ideal rhetorical agent' who has to study language in order to effectively communicate with and utilize authority and power. The findings suggest that the notions of kut and töre underwrite Kutadgu Bilig as the pillars of performing in/with language. Kut roughly represents a divinely sourced bliss. Töre refers to a certain set of moral principles that are supposed to guide and govern an individual's behavior--principles that, when followed, leads to an individual's eternal bliss and, when violated, might result in his or her demise. Rather than defining rhetoric as the moral person speaking (e.g., see Quintilian), Kutadgu Bilig suggests that attaining kut requires subjecting the 'tongue' to a certain rhetorical training (e.g., one has to study language so she or he can effectively communicate with and utilize authority and power) which ensures one's morality (proper following of the töre).

With its insights on the use of language, Kutadgu Bilig demonstrates the universal value of the study of rhetoric and can contribute to our explorations of alternative definitions and purposes of rhetoric (e.g., communicating to attain happiness). Such non-Western texts can present us with different sets of rhetorical conventions that raise interesting questions and can provide scholars with various points for critical discussion about how to exercise a moral understanding of rhetorical agency in our quest to advance civil discourse.

\section{Keywords:}

Agency, Civic, Cultural, Discourse, Intercultural, Literature, Morality, Rhetoric, Pedagogy 